\title{
EFEKTIVITAS MEDIA SOSIAL UNTUK GERAKAN SOSIAL PELESTARIAN LINGKUNGAN
}

\author{
Effectiveness of Social Media for Social Movements of Environmental Conservation \\ Dea Rizki Kapriani*) dan Djuana P. Lubis \\ Departemen Sains Komunikasi dan Pengembangan Masyarakat, Fakultas Ekologi Manusia, IPB \\ *)Email : dea.kapriani@gmail.com
}

\begin{abstract}
Social media in has become one of the media for social movement campaign of environmental preservation. KeSEMaT organization as a mangrove preservation organization that persuade society to participate through online activity by using @KeSEMaT and offline activity. This research aimed to describe the participation of@KeSEMaT followers in social media and the factors that influence it; to describe the effectiveness of @ KeSEMaT in changing behavior of @KeSEMaT followers and to analyze the relationship with participation in social media; to describe the participation of @KeSEMaT followers in offline activity and analyze the relationship of behavior change. The subject of this research is the follower of @KeSEMaT account.The research is used quantitive method that is supported by qualitative method. The results of this research shows that high involvement in social media can affect the follower to participate in KeSEMaT activity.
\end{abstract}

Keywords: followers, offline, online, social media, social movement

\begin{abstract}
ABSTRAK
Media sosial telah menjadi salah satu media untuk kampanye gerakan sosial pelestarian lingkungan. Organisasi KeSeMaT sebagai organisasi pelestarian mangrove yang mengajak masyarakat untuk berpartisipasi melalui aktivitas online dengan menggunakan@KeSEMaTdan aktivitas offline. Penelitian ini bertujuan untuk mendeskripsikan keterlibatan followers akun @KeSEMaT dalam media sosial dan analisis faktor-faktor yang mempengaruhinya, untuk mendeskripsikan efektivitas akun@KeSEMaT dalam menyebabkan perubahan perilaku followers dan analisis hubungannya dengan keterlibatan dalam media sosial, dan menganalisis keterlibatan followers akun@KeSEMaT dalam kegiatan offline dan analisis hubungannya dengan perubahan perilaku. Fokus penelitian ini adalah follower akun@KeSEMaT. Penelitian ini menggunakan metode kuantitatif yang didukung dengan metode kualitatif. Hasil penelitian ini menunjukkan bahwa tingginya keterlibatan dalam media sosial dapat mempengaruhi partisipasi dalam kegiatan KeSEMaT.
\end{abstract}

Kata kunci : gerakan sosial, media sosial, pengikut, offline

\section{PENDAHULUAN}

\section{Latar Belakang}

Perkembangan penggunaan internet di Indonesia, seperti yang dikutip oleh Nugroho (2011), menurut Purbo (2000) dimulai sejak tahun 1990an. Dikutip oleh Emarita (2012), menurut Laquey (1997) internet merupakan jaringan longgar dari ribuan komputer yang menjangkau jutaan orang di seluruh dunia. Misi awal dari internet adalah menyediakan sarana bagi para peneliti untuk mengakses data dari sejumlah sumber daya perangkat keras komputer yang mahal.

Saat ini internet digunakan sebagai media berkomunikasi di masyarakat melalui media sosial. Menurut Nugroho (2011) media sosial merupakan media online dengan para penggunanya bisa dengan mudah berpartisipasi, berbagi, dan menciptakan isi meliputi blog, jejaring sosial, wiki, forum, dan dunia virtual. Kaplan dan Haenlein (2010) mendefinisikan media sosial sebagai sebuah kelompok aplikasi berbasis internet yang membangun di atas dasar ideologi dan teknologi Web 2.0 dan yang memungkinkan penciptaan dan pertukaran user generated content. Dalam perkembangan media sosial kemudian muncul media jejaring sosial. Menurut Emarita (2012), media jejaring sosial merupakan situs dimana setiap orang bisa membuat web pribadi, kemudian terhubung dengan teman-teman untuk berbagi informasi dan berkomunikasi.

Fenomena yang muncul di Indonesia beberapa tahun terakhir adalah pemanfaatan media jejaring sosial untuk menghimpun anggota dalam suatu gerakan sosial tertentu. Pembentukan gerakan sosial diawali dengan adanya pembentukan suatu komunitas virtual yang didasarkan pada kesamaan minat, dan tujuan. Suatu contoh kasus pemanfaatan media sosial dalam menghimpun dukungan dalam gerakan sosial adalah kasus dari Prita Mulyasari yang menghimpun bantuan dana dalam bentuk koin untuk permasalahan kasus hukumnya. Menurut Nugroho (2011) 
efektivitas media sosial dalam gerakan sosial dibuktikan dalam waktu yang relatif singkat dapat menghimpun banyak dukungan dari para pengguna media sosial dan gerakan sosial tersebut mampu menghimpun aksi secara offline (bukan hanya click activism). Efektivitas dari media sosial terhadap individu dalam suatu gerakan sosial dapat dibuktikan dengan adanya perubahan perilaku yang dilatarbelakangi dengan keterlibatan dalam gerakan sosial tersebut baik online maupun offline. Perubahan perilaku dapat dilihat dari tindakan beberapa relawan dari gerakan sosial Indonesia Unite untuk membuat harian indonesia unite, dan@aksisosial_IU yang awalnya dilatarbelakangi oleh keikutsertaan dalam gerakan Indonesia Unite.

KeSEMaT (Kelompok Studi Ekosistem Mangrove Teluk Awur) merupakan organisasi unit kegiatan mahasiswa Universitas Diponegoro yang memiliki gerakan sosial pelestarian mangrove. Sebagai organisasi yang dimotori oleh mahasiswa, KeSEMaT banyak menggunakan media sosial sebagai saluran kampanye pelestarian mangrove. Kampanye yang dilakukan meliputi pemberian informasi mengenai keadaan ekosistem mangrove melalui berbagai akun media sosial yang dimiliki KeSEMaT. Selain kampanye tersebut, KeSEMaT juga memiliki usaha yang bergerak di bidang mangrove, dalam membuat jejaring usaha KeSEMaT juga memanfaatkan media sosial. Jumlah anggota gerakan KeSEMaT secara online dapat dikatakan cukup banyak. Berdasarkan pemaparan tersebut maka penting untuk menganalisis efektivitas gerakan sosial KeSEMaT yang memanfaatkan media sosial.

\section{Pertanyaan Penelitian}

1. Bagaimana keterlibatan followers dari akun @ KeSEMaT dan faktor-faktor yang mempengaruhinya?

2. Bagaimana efektivitas akun @KeSEMaT dalam mengubah perilaku followers dan analisis hubungannya dengan keterlibatan dalam media sosial?

3. Bagaimana keterlibatan followers akun @KeSEMaT dalam kegiatan offline KeSEMaT dan analisis hubungannya dengan perubahan perilaku followers?

\section{Tujuan Penelitian}

1. Deskripsi keterlibatan followers akun@KeSEMaT dalam media sosial dan analisis faktor-faktor yang mempengaruhinya.

2. Deskripsi efektivitas akun @KeSEMaT dalam menyebabkan perubahan perilaku followers, dan analisis hubungannya dengan keterlibatan dalam media sosial.

3. Deskripsi keterlibatan followers akun @KeSEMaT dalam kegiatan offline dan analisis hubungannya dengan perubahan perilaku.

\section{TINJAUAN PUSTAKA}

\section{Media Sosial dan Perkembangannya}

Kaplan dan Haenlein (2010) menjelaskan bahwa media sosial dapat dikelompokkan menjadi beberapa bagian besar dan diantaranya:

- Social Networks, media sosial untuk bersosialisasi dan berinteraksi (contohnya : Facebook, myspace, hi5, Linked in, bebo)
- $\quad$ Discuss, media sosial yang memfasilitasi sekelompok orang untuk melakukan obrolan dan diskusi (contohnya :google talk, yahoo! M, skype, phorum)

- Share, media sosial yang memfasilitasi kita untuk saling berbagi diantaranya file, video, music (youtube, slideshare, feedback, flickr, crowdstorm)

- Publish, (wordpredss, wikipedia, blog, wikia, digg)

- Micro blog media sosial yang untuk berinteraksi dan bersosialisasi akan tetapi ada batasan terhadap jumlah huruf yang ditulis (twitter, plurk, pownce, twirxr, plazes, tweetpeek)

Data yang dirilis oleh situs A World of Tweets Dot Com menempatkan Indonesia sebagai negara ketiga tebanyak di dunia dalam menulis tweet (kicauan) dalam situs jejaring sosial Twitter yaitu sebesar $11,39 \%$. Twitter adalah situs micro blogging yang dioperasikan Twitter, Inc. Twitter disebut micro blogging karena situs ini memungkinkan penggunanya mengirim dan membaca pesan seperti blog pada umumnya.

\section{Masyarakat Cyber dan Komunitas dalam Dunia Maya}

Menurut Bungin (2009) perkembangan teknologi informasi mampu menciptakan ruang gerak kehidupan baru bagi masyarakat, sehingga tanpa disadari komunitas manusia telah hidup dalam dua dunia kehidupan, yaitu kehidupan masyarakat nyata dan kehidupan masyarakat maya yang disebut cybercommunity.

\section{Gerakan Sosial}

Menurut Sztompka (2011) gerakan sosial adalah tindakan kolektif yang diorganisir secara longgar, tanpa terlembaga untuk menghasilkan perubahan dalam masyarakat mereka. Dikutip dari Ismail (2012), Singh (2009) menyatakan bahwa paradigma gerakan sosial baru bertumpu pada dua klaim paradigma utama yaitu :

- Gerakan sosial baru merupakan produk peralihan dari perekonomian industrial menuju post-industrial.

- Gerakan sosial baru berbeda dengan gerakan di era industrial. Jika gerakan tradisional biasanya lebih menekankan pada tujuan ekonomis-materil sebagaimana gerakan buruh, gerakan sosial baru cenderung menghindari tujuan tersebut dan menetapkan tujuan yang bersifat non ekonomis-materil.

\section{Pemanfaatan Media Sosial dalam Gerakan Sosial}

Penelitian Ahmad (2012) menceritakan mengenai Gerakan Akademi Berbagi yang memanfaatkan media sosial. Menurut Ahmad (2012) Gerakan Akademi Berbagi muncul didasarkan dengan keprihatinan biaya pendidikan yang mahal. Gerakan ini membentuk kelas-kelas gratis selama dua jam yang diajarkan oleh praktisi yang ahli dalam bidangnya masing-masing. Selama dua tahun Gerakan Akademi berbagi berkembang pesat, karena basis pergerakan Akademi Berbagi meliputi Twitter, Facebook, dan Website. Secara nasional Gerakan Akademi Berbagi memiliki akun Twitter@akademiberbagi, akun inilah yang mengatur dan mendistribusikan informasi kelas yang diadakan di setiap daerah yang ada. Melalui Facebook, Gerakan Akademi Berbagi menggunakan nama akun Akademi Berbagi dan Website dengan alamat www.akademiberbagi.org. Dalam dua tahun keberadaannya, Gerakan Akademi Berbagi telah 
hadir di 33 kota di Indonesia dan satu kota di Singapura. Gerakan Akademi Berbagi di berbagai kota, sebagai contoh : di Jakarta@AkberJKT,di Bogor@AkberBogor, di Bandung@AkberBDG dan di Semarang@AkberSMG.

\section{Gerakan Sosial dan Perilaku Individu}

Mann dalam Azwar (1995) mendefinisikan komponen kognitif berisikan, kepercayaan, dan streotype yang dimiliki individu mengenai sesuatu. Komponen afektif merupakan perasaan individu terhadap objek sikap dan menyangkut masalah emosi. Komponen konatif atau psikomotorik berisikan kecenderungan bertindak atau bereaksi terhadap sesuatu dengan cara-cara tertentu.

\section{Karakteristik Pengguna Media Sosial}

Menurut Darwin (2013) berdasarkan hasil lembaga riset MarkPlus Insight. Jumlah pengguna internet di Indonesia tumbuh signifikan hingga $22 \%$ dari 62 juta di tahun 2012 menjadi 74,57 juta di tahun 2013. Angka pengguna internet di Indonesia akan menembus 100 juta jiwa di tahun 2015 nanti. Netizen atau pengguna internet yang sehari-harinya menghabiskan waktu lebih dari tiga jam dalam dunia maya meningkat dari 24,2 juta di tahun 2012 menjadi 31,7 juta orang di tahun 2013.

Hampir separuh dari Netizen Indonesia merupakan pengguna internet muda dibawah 30 tahun, sedangkan 16\% adalah para Netizen berusia diatas 45 tahun. Bahkan hampir 95\% Netizen tersebut adalah pengguna internet melalui perangkat mobile (smartphone). Pada survei terlihat bahwa Netizen menghabiskan uangnya sekitar Rp.50 000- Rp100 000 untuk internet per-bulan, bahkan terdapat $16,8 \%$ Netizen yang rela mengeluarkan kocek di atas Rp150 000 per-bulan untuk keperluan internet.

\section{Gerakan Pelestarian Mangrove KeSEMaT}

Dalam upaya kampanye melalui Twitter, KeSEMaT juga membuat beberapa akun Twitter yang mendukung program kampanye pelestarian mangrove diantaranya :

a. @KeSEMaT, Kelompok Studi Ekosistem Mangrove Teluk Awur (KeSEMaT) merupakan akun resmi dari organisasi KeSEMaT

b. @KeMANGTEER, KeSEMaT Mangrove Volunteer merupakan akun resmi bagi para anggota diluar organisasi KeSEMaT yang ingin ikut berkontribusi dalam pelestarian mangrove

c. @Mas_Jamang, Merupakan akun resmi yang menjual berbagai makanan olahan berbahan dasar mangrove yang memiliki label Jajanan Mangrove (JAMANG) binaan KeSEMaT dan bekerjasama dengan pihak CSR.

d. @BatikBakau, Merupakan akun resmi penjualan batik yang berbahan dasar pewarna dari bakau, serta memiliki motif beraneka ragam yang berhubungan dengan mangrove. Batik Bakau merupakan salah satu produk dari usaha pemberdayaan masyarakat yang bekerjasama dengan KeSEMaT

e. @CV_KeMANGI, KeMANGI (KeSEMaT Mangrove Indonesia) merupakan akun resmi milik badan usaha KeSEMaT yaitu CV. KeMANGI

\section{Hipotesis Penelitian}

a. Terdapat hubungan antara karakteristik individu followers akun@KeSEMaT (umur, pendidikan, tempat tinggal, pekerjaan, pendapatan, pengeluaran untuk akses internet dan minat serta kepemilikan perangkat TIK) dengan keterlibatan dalam media sosial.

b. Terdapat hubungan antara keterlibatan dalam media sosial (frekuensi dan durasi) dengan perubahan perilaku individu (kognitif dan afektif).

c. Terdapat hubungan antara perubahan perilaku kognitif dan afektif dengan intensitas keikutsertaan secara offline dalam gerakan sosial.

\section{Kerangka Pemikiran}

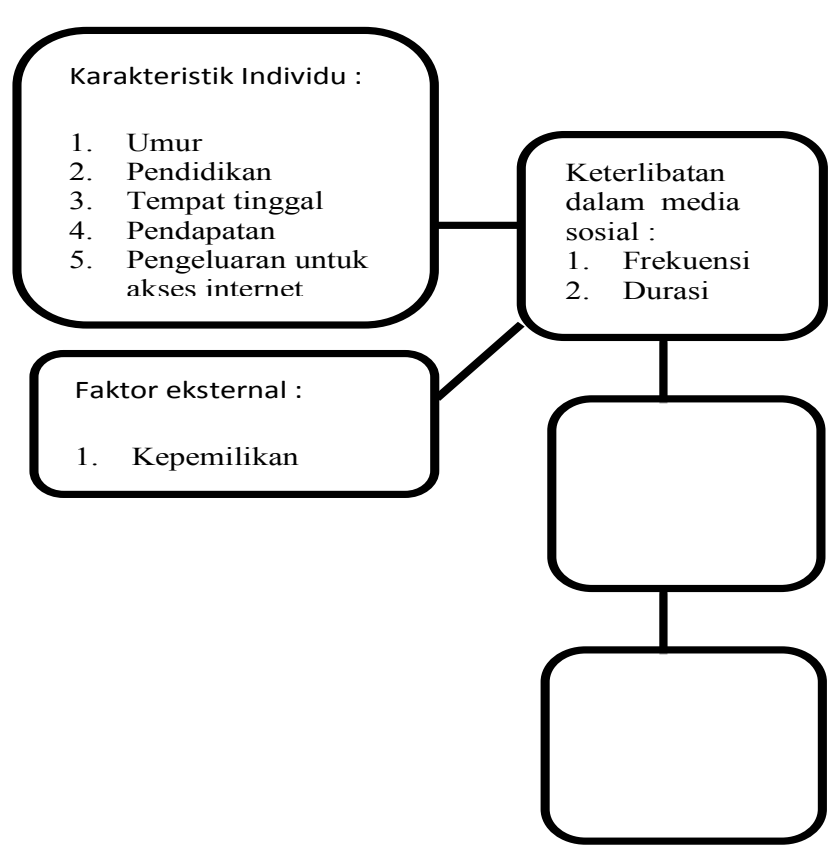

\section{METODE PENELITIAN}

\section{Lokasi dan Waktu Penelitian}

Penelitian ini dilakukan melalui dunia maya yaitu dengan memanfaatkan media sosial Twitter dalam penyebaran kuesioner kepada responden dan wawancara semi terstruktur dengan responden saat berlangsungnya kegiatan Mangrove Cultivation 2013 di Jepara 17 hingga 19 Mei 2013. Waktu penelitian dilaksanakan selama selama bulan Mei 2013.

Pemilihan KeSEMaT sebagai objek penelitian dilakukan dengan sengaja. KeSEMaT merupakan organisasi yang telah lama mengkampanyekan pelestarian mangrove. Dalam upaya kampanye gerakan sosial pelestarian mangrove KeSEMaT memanfaatkan media sosial yaitu Twitter dengan akun@KeSEMaT. Melalui akun@ KeSEMaT pihak admin secara rutin membuat tweet yang berisikan informasi dan seputar kegiatan kampanye KeSEMaT. Salah satu aksi offline KeSEMaT adalah Mangrove Cultivation (MC) yang hingga saat ini telah 
berjalan selama 6 tahun (sejak 2008). Kegiatan MC 2013 dilaksanakan pada tanggal 17 Mei hingga 19 Mei 2013

\section{Populasi dan Responden}

Populasi dalam penelitian ini adalah seluruh followers akun@KeSEMaT yang berjumlah 15000 followers (per10 Mei Pukul.00.00). Metode penelitian yang digunakan adalah nonprobability sampling dan teknik yang digunakan adalah accidental sampling. Menurut Sugiyono (2007) nonprobability sampling adalah teknik yang tidak memberi peluang/kesempatan yang sama bagi setiap unsur atau anggota populasi untuk dipilih menjadi sampel.

Metode non-probability sampling dipilih karena tidak semua followers akun@KeSEMaT dapat menjadi responden. Responden dipilih yang hanya telah menjadi followers akun@KeSEMaT sebelum tanggal 10 Mei 2013. Alasan pembatasan tersebut karena pada tanggal tersebut adalah batas dari pendaftaran kegiatan Mangrove Cultivation, sebagai kegiatan offline paling terbaru yang dilakukan KeSEMaT. Penentuan sampel berdasarkan followers yang bersedia untuk mengisi kuesioner. Jumlah sampel yang menjadi responden sebanyak 120 followers akun @ KeSEMaT.

\section{Teknik Pengolahan dan Analisis Data}

Unit analisis penelitian ini adalah individu. Data diolah menggunakan software SPSS for Windows versi 18.0 dan Microsoft Excel 2007. Langkah awal yaitu dengan pemberian skor pada setiap pertanyaan tentang karakteristik individu, faktor eksternal, keterlibatan dalam media sosial, perubahan perilaku, dan gerakan sosial. Setelah data primer dikumpulkan kemudian diolah dan dianalisis ke dalam bentuk tabulasi frekuensi dan tabulasi silang. Tabel frekuensi digunakan untuk menyajikan semua data yang telah diolah, sedangkan tabulasi silang digunakan untuk menganalisis hubungan antar variabel. Untuk menguji hubungan antar variabel ordinal digunakan metode statistik non parametrik Uji Korelasi Rank Spearman. Pengujian antar variabel nominal digunakan uji Chi-Square. Keeratan hubungan hasil uji korelasi Rank Spearman dan Chi-Square ditetapkan dengan kriteria seperti yang dikemukakan oleh Guilford (1956) dalam Rakhmat (2002) sebagai berikut:
a. $<0.20$
: hubungan rendah sekali; lemah sekali
b. $0.20-0.40$
: hubungan rendah tetapi pasti
c. $0.40-0.70$
: hubungan yang cukup berarti
d. $0.70-0.90$
: hubungan tinggi; kuat
e. $>0.90$
hubungan sangat tinggi; kuat sekali, dapat diandalkan

Tingkat kepercayaan yang digunakan dalam penelitian ini adalah $95 \%$ dengan nilai signifikansi sebesar $\alpha(0,05)$, artinya hasil penelitian mempunyai kesempatan untuk benar atau tingkat kepercayaan sebesar 95\% dan tingkat kesalahan $5 \%$.

\section{Karakteristik Responden}

Berdasarkan Tabel 1. karakteristik responden yang dominan yaitu, sebaran umur responden pada 18 hingga 26 tahun, sedang menempuh atau dengan pendidikan terakhir perguruan tinggi, bertempat tinggal di Pulau Jawa dan memiliki minat terhadap pelestarian mangrove sebelum menjadi followers akun@KeSEMaT.

Tabel 1. Jumlah dan Sebaran Responden Berdasarkan Individu

\begin{tabular}{lcr}
\hline Karakteristik Responden & Jumlah & Persentase (\%) \\
\hline Umur (tahun) & & 5.0 \\
Rendah $(<17)$ & 6 & 85.8 \\
Sedang (18-26) & 103 & 9.2 \\
Tinggi (>27) & 11 & \\
Pendidikan & & 3.3 \\
Rendah (SD-SMP) & 4 & 2.5 \\
Sedang (SMA) & 3 & 94.2 \\
Tinggi (Perguruan Tinggi) & 113 & \\
Pendapatan (Rp) & & 6.7 \\
Rendah & 8 &
\end{tabular}

$(<498437)$

Sedang

(498 438- 1382 244)

Tinggi

$(>1382$ 245)

Tempat Tinggal

Pulau Jawa

Luar Pulau Jawa

Pengeluaran Akses Internet (Rp)

Rendah

$(<54738)$

Sedang

(54 739-129 921)

Tinggi

$(>129$ 922)

Kepemilikan Perangkat TIK (skor)

Rendah $(<3)$
Sedang $(4-6)$
Tinggi $(>7)$

40

33.3

56

46.7

Minat Terhadap Pelestarian

Mangrove

Berminat

Tidak Berminat

15

12.5

\section{Keterbatasan penelitian}

Dalam penelitian ini perubahan perilaku tidak dapat diukur secara tepat, karena tidak ada post test dan pre test. Dalam pengisian aspek kognitif, responden dimungkinkan dapat menjawab kuesioner bukan berasal dari membaca tweet 
dari akun@KeSEMaT akan tetapi hal tersebut mungkin sudah menjadi pengetahuan bagi responden.

\section{Sejarah KeSEMaT}

Kelompok Studi Ekosistem Mangrove Teluk Awur (KeSEMaT) didirikan pada tanggal 9 Oktober 2001 oleh 9 orang mahasiswa angkatan 1998, Jurusan Ilmu Kelautan Universitas Diponegoro (UNDIP), Semarang di desa Teluk Awur, Jepara. Pada awal berdirinya, KeSEMaT memfokuskan diri untuk merehabilitasi lahan gundul di pesisir Teluk Awur. Organisasi ini memiliki motto "konservasi, penelitian, kampanye, pendidikan dan dokumentasi mangrove untuk generasi mendatang".

\section{Program Kerja KeSEMaT}

Program kerja KeSEMaT terdiri dari program kerja intern, ekstern dan insidental. Program kerja intern dikhususkan untuk memberikan bekal kepada para KeSEMaTER untuk memahami mangrove dengan lebih baik. Sementara itu, program kerja ekstern bertujuan untuk melibatkan masyarakat umum. Program kerja insidental merupakan program kerjasama antara KeSEMaT dengan CSR perusahaan, swasta dan dinas terkait untuk mengimplementasikan program di satu lokasi tertentu dalam satu periode tertentu.

\section{KETERLIBATAN FOLLOWERS DALAM MEDIA SOSIAL}

\section{Frekuensi dan Durasi Responden Akses Twitter}

Sebaran responden dengan tingkat frekuensi akses Twitter sedang memiliki jumlah persentase terbesar yaitu $58.3 \%$. Frekuensi akses Twitter rendah salah satu alasan yang dikemukakan salah seorang responden karena tidak terlalu tertarik berinteraksi dengan orang lain melalui media sosial. Sedangkan salah satu alasan yang dikemukakan responden yang memiliki frekuensi akses Twitter yang tinggi karena seringnya responden berinteraksi dengan orang lain melalui Twitter dengan berbalas mention.

Tabel 2. Jumlah dan Sebaran Responden Berdasarkan Frekuensi dan Durasi Akses Twitter.

\begin{tabular}{lll}
\hline $\begin{array}{l}\text { Keterlibatan dalam Media So- } \\
\text { sial }\end{array}$ & Jumlah & $\begin{array}{l}\text { Persentase } \\
(\%)\end{array}$ \\
\hline $\begin{array}{l}\text { Frekuensi (skor) } \\
\text { Rendah }(<5)\end{array}$ & 24 & 20.0 \\
Sedang (6-10) & 70 & 58.3 \\
Tinggi $(>11)$ & 26 & 21.7 \\
Durasi (skor) & & \\
Rendah $(<2)$ & 25 & 20.8 \\
Sedang $(3-5)$ & 81 & 67.5 \\
Tinggi $(>6)$ & 14 & 11.7 \\
\hline
\end{tabular}

Responden dengan tingkat durasi akses Twitter sedang berada pada persentase tertinggi yaitu $67.5 \%$. Beberapa alasan responden memiliki durasi pada kategori sedang dan tinggi pada saat akses Twitter adalah:
1. Mengobrol dengan akun lain dengan cara balas mention.

2. Mengikuti kuliah Twitter (kultwit) yang rutin diberikan beberapa akun Twitter.

3. Sedang ikut kuis di Twitter.

4. Mengikuti tips-tips yang sedang dibahas oleh akun Twitter lain.

5. Sedang ingin tahu sesuatu hal (kepo).

6. Membaca akun Twitter artis yang diidolakan.

7. Memiliki banyak waktu senggang.

8. Membaca berita.

\section{Hubungan Umur dengan Frekuensi dan Durasi Akses Twitter}

Hasil Tabel 3 menunjukkan responden dengan tingkat umur sedang dengan frekuensi akses Twitter sedang memiliki persentase paling banyak sebesar $88.7 \%$, sedangkan pada Tabel 4 responden dengan kategori tingkat umur sedang dan durasi akses Twitter tinggi memiliki persentase terbanyak yaitu $92.9 \%$. Hasil perhitungan melalui rank spearman antara umur dan frekuensi didapatkan nilai signifikansi sebesar 0.144 dengan koefisien korelasi sebesar 0.098 sedangkan hasil perhitungan melalui rank spearman didapatkan nilai signifikansi antara umur dan durasi keterlibatan dalam media sosial sebesar 0.068 dengan koefisien korelasi sebesar 0.137 hal ini menunjukkan terdapat hubungan yang tidak signifikan antara umur dengan frekuensi dan durasi. Hasil yang tidak signifikan diduga terjadi karena responden mengelompok pada kategori umur sedang yang berjumlah 103 responden atau $85.7 \%$ dari total 120 responden.

Tabel 3. Jumlah dan Persentase Responden Menurut Umur dan Frekuensi Mengakses Akun Twitter@ KeSEMaT

\begin{tabular}{|c|c|c|c|c|c|c|c|c|}
\hline \multirow{3}{*}{ Umur } & \multicolumn{6}{|c|}{ Frekuensi Akses Twitter } & \multirow{2}{*}{\multicolumn{2}{|c|}{ Jumlah }} \\
\hline & \multicolumn{2}{|c|}{ Rendah } & \multicolumn{2}{|c|}{ Sedang } & \multicolumn{2}{|c|}{ Tinggi } & & \\
\hline & $\mathrm{n}$ & $\%$ & $\mathrm{n}$ & $\%$ & $\mathrm{n}$ & $\%$ & $n$ & $\%$ \\
\hline Rendah & 3 & 12.5 & 2 & 2.9 & 1 & 3.9 & 6 & 5.0 \\
\hline $\begin{array}{l}\text { Se- } \\
\text { dang }\end{array}$ & 20 & 83.3 & 60 & 85.7 & 23 & 88.5 & 103 & 85.8 \\
\hline Tinggi & 1 & 4.2 & 8 & 11.4 & 2 & 7.6 & 11 & 9.2 \\
\hline & & & & & & & 120 & 100.0 \\
\hline
\end{tabular}

Tabel 4. Jumlah dan Persentase Responden Menurut Umur dan Durasi Mengakses Akun Twitter@KeSEMaT

\begin{tabular}{|c|c|c|c|c|c|c|c|c|}
\hline \multirow{3}{*}{ Umur } & \multicolumn{6}{|c|}{ Durasi Akses Twitter } & \multirow{2}{*}{\multicolumn{2}{|c|}{ Jumlah }} \\
\hline & \multicolumn{2}{|c|}{ Rendah } & \multicolumn{2}{|c|}{ Sedang } & \multicolumn{2}{|c|}{ Tinggi } & & \\
\hline & $\mathrm{n}$ & $\%$ & $\mathrm{n}$ & $\%$ & $\mathrm{n}$ & $\%$ & $\mathrm{n}$ & $\%$ \\
\hline Rendah & 4 & 16.0 & 2 & 2.5 & 0 & 0.0 & 6 & 5.0 \\
\hline $\begin{array}{l}\text { Se- } \\
\text { dang }\end{array}$ & 19 & 76.0 & 71 & 87.7 & 13 & 92.9 & 103 & 85.8 \\
\hline \multirow[t]{2}{*}{ Tinggi } & 2 & 8.0 & 8 & 9.8 & 1 & 7.1 & 11 & 9.2 \\
\hline & & & & & & & 120 & 100.0 \\
\hline
\end{tabular}




\section{Hubungan Tingkat Pendidikan dengan Frekuensi dan Durasi Akses Twitter}

Berdasarkan hasil perhitungan melalui rank spearman didapatkan hasil nilai signifikan antara pendidikan dan frekuensi keterlibatan dalam media sosial sebesar 0.031 dengan koefisien korelasi sebesar 0.171 terdapat hubungan yang signifikan antara pendidikan dan frekuensi keterlibatan dalam media sosial dengan tingkat hubungan yang rendah sekali. Hasil Tabel 5 menunjukkan responden dengan kategori pendidikan tinggi dengan tingkat frekuensi sedang memiliki jumlah responden terbanyak dengan persentase $97.1 \%$. Persentase responden pada tingkat pendidikan tinggi dengan frekuensi akses Twitter sedang dan tinggi jumlahnya tidak terlalu berbeda. Responden dengan tingkat frekuensi akses Twitter tinggi, umumnya memanfaatkan Twitter selain sebagai sarana untuk mendapatkan informasi seputar berita terkini, juga memanfaatkan Twitter sebagai media untuk berkomunikasi dengan pengguna Twitter lainnya.

Pada Tabel 6 responden dengan kategori tingkat pendidikan tinggi dengan durasi akses Twitter tinggi memiliki persentase responden terbanyak sebesar $100.0 \%$. Hasil perhitungan melalui rank spearman didapatkan korelasi antara tingkat pendidikan dan durasi keterlibatan dalam media sosial sebesar 0.001 dengan koefisien korelasi sebesar 0.282 terdapat hubungan yang signifikan antara tingkat pendidikan dan durasi keterlibatan dalam media sosial dengan tingkat hubungan yang rendah tapi pasti. Berdasarkan hasil FGD salah satu peserta FGD yang merupakan mahasiswa menyatakan durasi waktu mengakses Twitter lebih banyak digunakan untuk membaca berita.

Tabel 5. Jumlah dan Persentase Responden Menurut Tingkat Pendidikan dan Frekuensi Mengakses Akun Twitter@KeSEMaT

\begin{tabular}{lcccccccr}
\hline $\begin{array}{l}\text { Tingkat } \\
\begin{array}{l}\text { Pendi- } \\
\text { dikan }\end{array}\end{array}$ & \multicolumn{6}{c}{ Frekuensi Akses Twitter } & & \\
\cline { 2 - 7 } & Rendah & Sedang & \multicolumn{2}{c}{ Tinggi } & & Jumlah \\
\hline Rendah & 2 & 8.3 & 2 & 2.9 & 0 & 0.0 & 4 & 3.3 \\
Sedang & 2 & 8.3 & 0 & 0.0 & 1 & 3.9 & 3 & 2.5 \\
Tinggi & 20 & 83.4 & 68 & 97.1 & 25 & 96.1 & 113 & 94.2 \\
& & & & & & & 120 & 100.0
\end{tabular}

Tabel 6. Jumlah dan Persentase Responden Menurut Tingkat Pendidikan dan Durasi Mengakses Akun Twitter@KeSEMaT

\begin{tabular}{|c|c|c|c|c|c|c|c|c|}
\hline \multirow{3}{*}{$\begin{array}{l}\text { Tingkat } \\
\text { Pendi- } \\
\text { dikan }\end{array}$} & \multicolumn{6}{|c|}{ Durasi Akses Twitter } & \multirow{2}{*}{\multicolumn{2}{|c|}{ Jumlah }} \\
\hline & \multicolumn{2}{|c|}{ Rendah } & \multicolumn{2}{|c|}{ Sedang } & \multicolumn{2}{|c|}{ Tinggi } & & \\
\hline & $\mathrm{n}$ & $\%$ & $\mathrm{n}$ & $\%$ & $\mathrm{n}$ & $\%$ & $\mathrm{n}$ & $\%$ \\
\hline Rendah & 3 & 12.0 & 1 & 1.2 & 0 & 0.0 & 4 & 3.3 \\
\hline Sedang & 2 & 8.0 & 1 & 1.2 & 0 & 0.0 & 3 & 2.5 \\
\hline \multirow[t]{2}{*}{ Tinggi } & 20 & 80.0 & 79 & 97.6 & 14 & 100.0 & 113 & 94.2 \\
\hline & & & & & & & 120 & 100.0 \\
\hline
\end{tabular}

Hubungan Tingkat Pendapatan dengan Frekuensi dan Durasi Akses Twitter

Berdasarkan hasil perhitungan melalui rank spearman didapatkan hasil nilai signifikan antara tingkat pendapatan dan frekuensi keterlibatan dalam media sosial sebesar 0.010 dengan koefisien korelasi sebesar 0.212 terdapat hubungan yang signifikan antara penghasilan dan frekuensi dengan tingkat hubungan rendah tapi pasti. Hasil dari Tabel 7 diketahui responden pada tingkat pendapatan sedang dengan frekuensi akses Twitter rendah memiliki jumlah persentase terbanyak yaitu $70.8 \%$. Salah satu responden mengakui bahwa pendapatannya lebih banyak dialokasikan untuk memenuhi kebutuhan pokok dibandingkan untuk mendapatkan akses internet. Saat mengakses internet responden lebih memanfaatkannya untuk mencari literatur untuk tugas dibandingkan akses Twitter.

Tabel 7. Jumlah dan Persentase Responden Menurut Tingkat Pendapatan dan Frekuensi Mengakses Akun Twitter@KeSEMaT

\begin{tabular}{lcccccccr}
\hline \multirow{2}{*}{$\begin{array}{l}\text { Tingkat } \\
\begin{array}{l}\text { Pendapa- } \\
\text { tan }\end{array}\end{array}$} & \multicolumn{6}{c}{ Frekuensi Akses Twitter } & & \\
\cline { 2 - 6 } & Rendah & Sedang & \multicolumn{2}{c}{ Tinggi } & & Jumlah \\
\hline Rendah & 3 & 12.5 & 5 & 7.1 & 0 & 0.0 & 8 & 6.7 \\
Sedang & 17 & 70.8 & 30 & 42.9 & 14 & 53.8 & 61 & 50.8 \\
Tinggi & 4 & 16.7 & 35 & 50.0 & 12 & 46.2 & 51 & 42.5 \\
& & & & & & & 120 & 100.0 \\
\hline
\end{tabular}

Akan tetapi hasil dari Tabel 7 juga menunjukkan responden pada tingkat pendapatan sedang dengan frekuensi akses Twitter tinggi juga memiliki jumlah yang cukup besar yaitu $53.8 \%$. Salah satu responden menyatakan dirinya memilih menggunakan provider telekomunikasi yang menawarkan biaya langganan internet murah dengan kuota internet besar sehingga dengan tingkat pendapatan sedang, responden dapat akses internet terutama Twitter tanpa batasan.

Tabel 8. Jumlah dan Persentase Responden Menurut Tingkat Pendapatan dan Durasi Mengakses Akun Twitter@KeSEMaT

\begin{tabular}{|c|c|c|c|c|c|c|c|c|}
\hline \multirow{3}{*}{$\begin{array}{l}\text { Tingkat } \\
\text { Pendapa- } \\
\tan \end{array}$} & \multicolumn{6}{|c|}{ Durasi Akses Twitter } & \multicolumn{2}{|c|}{ Jumlah } \\
\hline & \multicolumn{2}{|c|}{ Rendah } & \multicolumn{2}{|c|}{ sedang } & \multicolumn{2}{|c|}{ Tinggi } & \multirow[b]{2}{*}{$\mathrm{n}$} & \multirow[b]{2}{*}{$\%$} \\
\hline & $\mathrm{n}$ & $\%$ & $\mathrm{n}$ & $\%$ & $\mathrm{n}$ & $\%$ & & \\
\hline Rendah & 5 & 20.0 & 3 & 3.7 & 0 & 0.0 & 8 & 6.7 \\
\hline Sedang & 13 & 52.0 & 43 & 53.1 & 5 & 35.7 & 61 & 50.8 \\
\hline \multirow[t]{2}{*}{ Tinggi } & 7 & 28.0 & 35 & 43.2 & 9 & 64.3 & 51 & 42.5 \\
\hline & & & & & & & 120 & 100.0 \\
\hline
\end{tabular}

Hasil dari Tabel 8 menunjukkan jumlah persentase terbesar terdapat pada tingkat pendapatan tinggi dengan durasi akses Twitter tinggi sebesar $64.3 \%$. Salah satu responden menyatakan bahwa dirinya lebih banyak menghabiskan waktu untuk akses dengan internet saat bekerja dengan menggunakan PC dikantornya. Responden biasanya selalu membuka akun Twitternya saat dikantor, sehingga saat 
senggang responden biasanya menghabiskan waktunya untuk membaca link informasi berita di Twitter, atau sekedar membaca Time Line.

Berdasarkan hasil perhitungan melalui rank spearman didapatkan hasil nilai signifikan antara tingkat pendapatan dan durasi keterlibatan dalam media sosial sebesar 0.003 dengan koefisien korelasi sebesar 0.250. Terdapat hubungan yang signifikan antara penghasilan dan durasi dengan tingkat hubungan rendah tapi pasti.

\section{Hubungan Tingkat Pengeluaran Akses Internet dengan Frekuensi dan Durasi Akses Twitter}

Berdasarkan hasil perhitungan melalui rank spearman didapatkan hasil nilai signifikan antara tingkat biaya yang dikeluarkan untuk akses internet dan frekuensi keterlibatan dalam media sosial sebesar 0.001 dengan koefisien korelasi sebesar 0.273 terdapat hubungan yang signifikan antara biaya yang dikeluarkan untuk akses internet dengan frekuensi dan tingkat hubungan rendah tapi pasti.

Hasil Tabel 9 menunjukkan responden pada tingkat pengeluaran untuk akses internet sedang, dengan frekuensi akses Twitter sedang memiliki jumlah persentase paling banyak sebesar 55.7\%. Hal ini dimungkinkan karena sekarang seseorang dapat berlangganan paket internet dengan harga yang relatif terjangkau. Akan tetapi yang menjadi persoalan adalah jaringan internet dari provider telekomunikasi yang digunakan. Salah satu responden mengungkapkan handphonenya selalu online terhadap Twitter akan tetapi karena aktivitasnya banyak dihabiskan dikampus dan jaringan internet dari provider telekomunikasi yang digunakan tidak terlalu baik dikampusnya sehingga frekuensi akses Twitternya tidak terlalu sering. Responden menjadi lebih mudah akses Twitter saat berada diluar lingkungan kampus.

Hasil perhitungan melalui rank spearman didapatkan nilai signifikansi antara biaya yang dikeluarkan untuk akses internet dan durasi keterlibatan dalam media sosial sebesar 0.045 dengan koefisien korelasi sebesar 0.156 terdapat hubungan yang signifikan antara biaya yang dikeluarkan untuk akses internet dan durasi keterlibatan dalam media sosial dengan tingkat hubungan yang rendah sekali.

Hasil Tabel 10 menunjukkan responden pada tingkat pengeluaran sedang dan durasi akses Twitter sedang memiliki jumlah persentase terbanyak yaitu sebesar $56.7 \%$. Biaya berlangganan akses internet saat ini sudah lebih murah, akan tetapi kendala yang dialami responden yaitu masih kurangnya jaringan internet yang memadai terutama bagi provider yang menawarkan paket internet yang murah. Untuk mendapatkan jaringan internet yang baik maka biaya yang dikeluarkan harus lebih besar (provider lain) atau biasanya memanfaatkan fasilitas Wi-Fi. Responden dengan pada pengeluaran biaya internet yang sedang biasanya memanfaatkan waktu-waktu tertentu saat koneksi internet sedang baik sehingga dapat mengakses Twitter tanpa kendala.

\section{Hubungan Tempat Tinggal dengan Durasi dan Frekuensi Akses Twitter}

Nilai p-value dari analisis chi Square sebesar $0.698>0.05$ maka H0 diterima. Sehingga tidak terdapat hubungan signifikan antara tempat tinggal dan frekuensi akses Twitter. Hal ini diduga sebaran responden mengelompok pada yang berada di Pulau Jawa yaitu sebanyak 107 responden, sedangkan responden di luar Pulau Jawa yang jumlahnya jauh berbeda yaitu 13 responden. Hasil Tabel 11 menunjukkan bahwa responden yang berada di Pulau Jawa memiliki jumlah persentase frekuensi akses Twitter yang cenderung tidak jauh berbeda pada frekuensi rendah, sedang, dan tinggi. Nilai p-value dari analisis chi square sebesar $0.867>0.05$ maka H0 diterima. Sehingga tidak terdapat hubungan signifikan antara tempat tinggal dan durasi akses Twitter. Hal ini diduga karena sebaran responden mengelompok pada yang berada di Pulau Jawa yaitu sebanyak 107 responden, sedangkan responden di luar Pulau Jawa yang jumlahnya jauh berbeda yaitu 13 responden.

Tabel 9. Jumlah dan Persentase Responden Menurut Tingkat Pengeluaran Akses Internet dan Frekuensi Mengakses Akun Twitter@KeSEMaT

\begin{tabular}{|c|c|c|c|c|c|c|c|c|}
\hline \multirow{3}{*}{$\begin{array}{l}\text { Tingkat } \\
\text { Pengelu- } \\
\text { aran }\end{array}$} & \multicolumn{6}{|c|}{ Frekuensi Akses Twitter } & \multirow{2}{*}{\multicolumn{2}{|c|}{ Jumlah }} \\
\hline & \multicolumn{2}{|c|}{ Rendah } & \multicolumn{2}{|c|}{ Sedang } & \multicolumn{2}{|c|}{ Tinggi } & & \\
\hline & $\mathrm{n}$ & $\%$ & $\mathrm{n}$ & $\%$ & $n$ & $\%$ & $\mathrm{n}$ & $\%$ \\
\hline Rendah & 10 & 41.7 & 15 & 21.4 & 3 & 11.5 & 28 & 23.3 \\
\hline Sedang & 10 & 41.7 & 39 & 55.7 & 11 & 42.3 & 60 & 50.0 \\
\hline \multirow[t]{2}{*}{ Tinggi } & 4 & 16.6 & 16 & 22.9 & 12 & 46.2 & 32 & 26.7 \\
\hline & & & & & & & 120 & 100.0 \\
\hline
\end{tabular}

Tabel 10. Jumlah dan Persentase Menurut Tingkat Pengeluaran Akses Internet dan Durasi Mengakses Akun Twitter@KeSEMaT

\begin{tabular}{|c|c|c|c|c|c|c|c|c|}
\hline \multirow{3}{*}{$\begin{array}{l}\text { Ting- } \\
\text { kat } \\
\text { Penge- } \\
\text { luaran }\end{array}$} & \multicolumn{6}{|c|}{ Durasi Akses Twitter } & \multirow{2}{*}{\multicolumn{2}{|c|}{ Jumlah }} \\
\hline & \multicolumn{2}{|c|}{ Rendah } & \multicolumn{2}{|c|}{ Sedang } & \multicolumn{2}{|c|}{ Tinggi } & & \\
\hline & $\mathrm{n}$ & $\%$ & $\mathrm{n}$ & $\%$ & $\mathrm{n}$ & $\%$ & $\mathrm{n}$ & $\%$ \\
\hline Rendah & 11 & 44.0 & 14 & 17.2 & 3 & 21.4 & 28 & 23.3 \\
\hline $\begin{array}{l}\text { Se- } \\
\text { dang }\end{array}$ & 8 & 32.0 & 46 & 56.7 & 6 & 42.9 & 60 & 50.0 \\
\hline \multirow[t]{2}{*}{ Tinggi } & 6 & 24.0 & 21 & 25.9 & 5 & 35.7 & 32 & 26.7 \\
\hline & & & & & & & 120 & 100.0 \\
\hline
\end{tabular}

Tabel 11. Jumlah dan Persentase Responden Menurut Tempat Tinggal dan Frekuensi Mengakses Akun Twitter@KeSEMaT

\begin{tabular}{|c|c|c|c|c|c|c|c|c|}
\hline \multirow{3}{*}{$\begin{array}{l}\text { Tempat } \\
\text { Tinggal }\end{array}$} & \multicolumn{6}{|c|}{ Frekuensi Akses Twitter } & \multirow{2}{*}{\multicolumn{2}{|c|}{ Jumlah }} \\
\hline & \multicolumn{2}{|c|}{ Rendah } & \multicolumn{2}{|c|}{ Sedang } & \multicolumn{2}{|c|}{ Tinggi } & & \\
\hline & $\mathrm{n}$ & $\%$ & $\mathrm{n}$ & $\%$ & $\mathrm{n}$ & $\%$ & $\mathrm{n}$ & $\%$ \\
\hline $\begin{array}{l}\text { Luar } \\
\text { Pulau } \\
\text { Jawa }\end{array}$ & 2 & 8.3 & 9 & 12.9 & 2 & 7.7 & 13 & 10.8 \\
\hline $\begin{array}{l}\text { Pulau } \\
\text { Jawa }\end{array}$ & 22 & 91.7 & 61 & 87.1 & 24 & 92.3 & 107 & 89.2 \\
\hline & & & & & & & 120 & 100.0 \\
\hline
\end{tabular}


Tabel 12. Jumlah dan Persentase Responden Menurut Tempat Tinggal dan Durasi Mengakses Akun Twitter (a)KEMaT

\begin{tabular}{lccccccccr}
\hline & \multicolumn{4}{c}{ Durasi Akses Twitter } & Jumlah \\
\cline { 2 - 9 } $\begin{array}{l}\text { Tempat } \\
\text { Tinggal }\end{array}$ & Rendah & \multicolumn{3}{c}{ Sedang } & \multicolumn{3}{c}{ Ting- } \\
\hline & $\mathrm{n}$ & $\%$ & $\mathrm{n}$ & $\%$ & $\mathrm{n}$ & $\%$ & $\mathrm{n}$ & $\%$ \\
\hline $\begin{array}{l}\text { Luar Pu- } \\
\text { lau Jawa }\end{array}$ & 2 & 8.3 & 9 & 11.0 & 2 & 14.3 & 13 & 10.8 \\
$\begin{array}{l}\text { Pulau } \\
\text { Jawa }\end{array}$ & 22 & 91.7 & 73 & 89.0 & 12 & 85.7 & 107 & 89.2 \\
& & & & & & & & \\
\hline
\end{tabular}

Hubungan Minat Terhadap Pelestarian Mangrove dengan Frekuensi dan Durasi Akses Twitter

Nilai p-value dari analisis chi square sebesar $0.109>0.05$ maka H0 diterima. Sehingga tidak terdapat hubungan signifikan antara minat terhadap pelestarian mangrove dan frekuensi akses Twitter. Berdasarkan hasil wawancara dengan responden dapat diketahui bahwa responden lebih tertarik untuk mengetahui lebih dalam mengenai mangrove melalui website KeSEMaT dibandingkan membaca melalui Twitter karena merasa informasi yang disampaikan terlalu singkat dibandingkan melalui website KeSEMaT.

Nilai p-value dari analisis chi square sebesar $0.003<0.05$ maka H0 ditolak. Sehingga terdapat hubungan signifikan antara minat dan durasi akses Twitter. Berdasarkan hasil wawancara mendalam dengan responden, melalui akun @ KeSEMaT pihak KeSEMaT sering memberikan kuliah Twitter (kultwit) mengenai mangrove. Sebelum @ KeSEMaT memberikan kultwit tersebut pihak admin akan memberitahu beberapa jam sebelumnya bahwa kultwit akan diberikan pada jam tertentu, sehingga responden akan membaca tweet yang disampaikan oleh pihak@KeSEMaT sampai kultwit selesai dan apabila ada pertanyaan mengenai kultwit responden akan menanyakan kepada akun@KeSEMaT melalui Twitter.

\section{Hubungan Kepemilikan Perangkat TIK dengan Frekuensi Akses Twitter}

Berdasarkan hasil perhitungan melalui rank spearman didapatkan hasil nilai signifikan antara kepemilikan perangkat TIK dan frekuensi keterlibatan dalam media sosial sebesar 0.007 dengan koefisien korelasi sebesar 0.223 terdapat hubungan yang signifikan antara kepemilikan perangkat TIK dan frekuensi dengan tingkat hubungan rendah tapi pasti. Responden dengan kategori kepemilikan perangkat TIK sedang, setidaknya responden tersebut memiliki smartphone atau handphone.

Keberadaan smartphone atau handphone yang dapat terhubung dengan internet memberi kemudahan dalam mengakses internet sehingga dapat mempengaruhi frekuensi akses Twitter. Salah satu responden menyatakan saat dirinya menggunakan smartphone frekuensi mengakses Twitter menjadi lebih sering, akan tetapi smartphonenya tidak selalu terhubung dengan Twitter karena dapat menyebabkan baterai smartphonenya cepat habis. Hal ini sesuai dengan hasil dari Tabel 15 yaitu jumlah responden dengan kepemilikan perangkat TIK sedang dengan frekuensi akses Twitter sedang memiliki jumlah persentase terbanyak yaitu 51.4\%.

Berdasarkan hasil perhitungan melalui rank spearman didapatkan hasil korelasi antara tingkat kepemilikan perangkat TIK dan durasi keterlibatan dalam media sosial sebesar 0.002 dengan koefisien korelasi sebesar 0.267. Terdapat hubungan yang signifikan antara kepemilikan perangkat TIK dan durasi dengan tingkat hubungan rendah tapi pasti.

Responden pada tingkat kepemilikan perangkat TIK sedang dan durasi akses Twitter tinggi memiliki persentase terbanyak sebesar $64.3 \%$. Hal ini sesuai dengan hasil wawancara yang menunjukkan kepemilikan perangkat TIK yang lebih canggih mampu menunjang durasi akses Twitter.

Tabel 13. Jumlah dan Persentase Responden Menurut Minat Terhadap Pelestarian Mangrove dan Frekuensi Mengakses Akun Twitter@KeSEMaT

\begin{tabular}{|c|c|c|c|c|c|c|c|c|}
\hline \multirow{3}{*}{ Minat } & \multicolumn{6}{|c|}{ Frekuensi Akses Twitter } & \multirow{2}{*}{\multicolumn{2}{|c|}{ Jumlah }} \\
\hline & \multicolumn{2}{|c|}{ Rendah } & \multicolumn{2}{|c|}{ Sedang } & \multicolumn{2}{|c|}{ Tinggi } & & \\
\hline & $\mathrm{n}$ & $\%$ & $\mathrm{n}$ & $\%$ & $\mathrm{n}$ & $\%$ & $\mathrm{n}$ & $\%$ \\
\hline $\begin{array}{l}\text { Tidak } \\
\text { Bermi- } \\
\text { nat }\end{array}$ & 5 & 20.8 & 5 & 7.1 & 5 & 19.2 & 15 & 12.5 \\
\hline \multirow{2}{*}{$\begin{array}{l}\text { Bermi- } \\
\text { nat }\end{array}$} & 19 & 79.2 & 65 & 92.9 & 21 & 80.8 & 105 & 87.5 \\
\hline & & & & & & & 120 & 100.0 \\
\hline
\end{tabular}

Tabel 14. Jumlah dan Persentase Responden Menurut Minat Terhadap Pelestarian Mangrove dan Frekuensi Mengakses Akun Twitter@KeSEMaT

\begin{tabular}{|c|c|c|c|c|c|c|c|c|}
\hline \multirow{3}{*}{ Minat } & \multicolumn{6}{|c|}{ Durasi Akses Twitter } & \multirow{2}{*}{\multicolumn{2}{|c|}{ Jumlah }} \\
\hline & \multicolumn{2}{|c|}{ Rendah } & \multicolumn{2}{|c|}{ Sedang } & \multicolumn{2}{|c|}{ Tinggi } & & \\
\hline & $\mathrm{n}$ & $\%$ & $\mathrm{n}$ & $\%$ & $\mathrm{n}$ & $\%$ & $\mathrm{n}$ & $\%$ \\
\hline $\begin{array}{l}\text { Tidak } \\
\text { Bermi- } \\
\text { nat }\end{array}$ & 8 & 32.0 & 5 & 6.1 & 2 & 14.3 & 15 & 12.5 \\
\hline $\begin{array}{l}\text { Bermi- } \\
\text { nat }\end{array}$ & 17 & 68.0 & 76 & 93.9 & 12 & 85.7 & 105 & 87.5 \\
\hline & & & & & & & 120 & 100.0 \\
\hline
\end{tabular}

Tabel 15. Jumlah dan Persentase Responden Menurut Kepemilikan Perangkat TIK dan Frekuensi Mengakses Akun Twitter@KeSEMaT

\begin{tabular}{|c|c|c|c|c|c|c|c|c|}
\hline \multirow{2}{*}{$\begin{array}{l}\text { Kepemi- } \\
\text { likan } \\
\text { Perang- } \\
\text { kat TIK } \\
\end{array}$} & \multicolumn{6}{|c|}{ Frekuensi Akses Twitter } & \multirow{2}{*}{\multicolumn{2}{|c|}{ Jumlah }} \\
\hline & \multicolumn{2}{|c|}{ Rendah } & \multicolumn{2}{|c|}{ Sedang } & \multicolumn{2}{|c|}{ Tinggi } & & \\
\hline & $\mathrm{n}$ & $\%$ & $\mathrm{n}$ & $\%$ & $\mathrm{n}$ & $\%$ & $\mathrm{n}$ & $\%$ \\
\hline Rendah & 12 & 50.0 & 23 & 32.9 & 5 & 19.2 & 40 & 33.3 \\
\hline Sedang & 8 & 33.3 & 36 & 51.4 & 12 & 46.1 & 56 & 46.7 \\
\hline \multirow[t]{2}{*}{ Tinggi } & 4 & 16.7 & 11 & 15.7 & 9 & 34.7 & 24 & 20.0 \\
\hline & & & & & & & 120 & 100.0 \\
\hline
\end{tabular}


Tabel 16. Jumlah dan Persentase Responden Menurut Kepemilikan Perangkat TIK dan Durasi Mengakses Akun Twitter@KeSEMaT

\begin{tabular}{lcccccccc}
\hline \multirow{2}{*}{$\begin{array}{l}\text { Kepemi- } \\
\text { likan }\end{array}$} & \multicolumn{9}{c}{ Durasi Akses Twitter } & \multirow{2}{*}{ Jumlah } \\
\cline { 2 - 7 } Perang- & \multicolumn{2}{c}{ Rendah } & \multicolumn{2}{c}{ Sedang } & \multicolumn{2}{c}{ Tinggi } & & \\
\cline { 2 - 8 } kat TIK & $\mathrm{n}$ & $\%$ & $\mathrm{n}$ & $\%$ & $\mathrm{n}$ & $\%$ & $\mathrm{n}$ & $\%$ \\
\hline Rendah & 14 & 56.0 & 25 & 30.8 & 1 & 7.1 & 40 & 33.3 \\
Sedang & 8 & 32.0 & 39 & 48.3 & 9 & 64.3 & 56 & 46.7 \\
Tinggi & 3 & 12.0 & 17 & 20.9 & 4 & 28.6 & 24 & 20.0 \\
& & & & & & & 120 & 100.0 \\
\hline
\end{tabular}

\section{EFEKTIVITAS MEDIA SOSIAL TWITTER} TERHADAP PERUBAHAN PERILAKU

\section{Aspek Kognitif dan Afektif Responden}

Tabel 17. Jumlah dan Sebaran Responden Berdasarkan Aspek Kognitif Dan Afektif

\begin{tabular}{lcc}
\hline $\begin{array}{l}\text { Efektivitas Perubahan } \\
\text { Perilaku }\end{array}$ & Jumlah & Persentase (\%) \\
\hline Kognitif (skor) & & \\
Rendah (<14) & 32 & 26.7 \\
Sedang (15-17) & 63 & 52.5 \\
Tinggi $(>18)$ & 25 & 20.8 \\
Afektif (skor) & & \\
Rendah (<29) & 16 & 13.3 \\
Sedang (30-39 & 75 & 62.5 \\
Tinggi $(>40)$ & 29 & 24.2 \\
\hline
\end{tabular}

Hubungan Frekuensi dan Durasi Akses Twitter dengan Aspek Kognitif

Tabel 18. Jumlah dan Persentase Responden Menurut Frekuensi Mengakses Akun Twitter@KeSEMaT dan Aspek Kognitif

\begin{tabular}{|c|c|c|c|c|c|c|c|c|}
\hline \multirow{3}{*}{$\begin{array}{l}\text { Frekuen- } \\
\text { si } \\
\text { Akses } \\
\text { Twitter }\end{array}$} & \multicolumn{6}{|c|}{ Aspek Kognitif } & \multirow{2}{*}{\multicolumn{2}{|c|}{ Jumlah }} \\
\hline & \multicolumn{2}{|c|}{ Rendah } & \multicolumn{2}{|c|}{ Sedang } & \multicolumn{2}{|c|}{ Tinggi } & & \\
\hline & $\mathrm{n}$ & $\%$ & $\mathrm{n}$ & $\%$ & $\mathrm{n}$ & $\%$ & $\mathrm{n}$ & $\%$ \\
\hline Rendah & 11 & 34.4 & 12 & 19.1 & 1 & 4.0 & 24 & 20.0 \\
\hline Sedang & 15 & 46.9 & 35 & 55.6 & 20 & 80.0 & 70 & 58.3 \\
\hline \multirow[t]{2}{*}{ Tinggi } & 6 & 18.7 & 16 & 25.3 & 4 & 16.0 & 26 & 21.7 \\
\hline & & & & & & & 120 & 100.0 \\
\hline
\end{tabular}

Berdasarkan hasil perhitungan melalui rank spearman didapatkan hasil nilai signifikan antara tingkat frekuensi dan perubahan perilaku kognitif sebesar 0.048 dengan koefisien korelasi sebesar 0.152 terdapat hubungan yang signifikan antara tingkat frekuensi keterlibatan dalam media sosial dan perubahan perilaku kognitif dengan tingkat hubungan yang rendah sekali. Sedangkan hasil perhitungan melalui rank spearman didapatkan hasil nilai signifikansi antara tingkat durasi dan perubahan perilaku kognitif sebesar 0.000 dengan koefisien korelasi sebesar 0.350 terdapat hubungan yang signifikan antara tingkat durasi keterlibatan dalam media sosial dan perubahan perilaku kognitif dengan tingkat hubungan rendah tapi pasti.

Hasil Tabel 18 menunjukkan jumlah persentase responden dengan frekuensi akses Twitter sedang dan aspek kognitif tinggi memiliki persentase terbesar sebanyak $80.0 \%$. Hal ini menunjukkan diduga responden mungkin mengetahui tentang mangrove tidak hanya melalui Twitter@KeSEMaT akan tetapi responden memang telah memiliki pengetahuan mengenai mangrove.

Tabel 19. Jumlah dan Persentase Responden Menurut Durasi Mengakses Akun Twitter@KeSEMaT dan Aspek Kognitif

\begin{tabular}{|c|c|c|c|c|c|c|c|c|}
\hline \multirow{3}{*}{$\begin{array}{l}\text { Durasi } \\
\text { Akses } \\
\text { Twitter } \\
\end{array}$} & \multicolumn{6}{|c|}{ Aspek Kognitif } & \multirow{2}{*}{\multicolumn{2}{|c|}{ Jumlah }} \\
\hline & \multicolumn{2}{|c|}{ Rendah } & \multicolumn{2}{|c|}{ Sedang } & \multicolumn{2}{|c|}{ Tinggi } & & \\
\hline & $\mathrm{n}$ & $\%$ & $\mathrm{n}$ & $\%$ & $\mathrm{n}$ & $\%$ & $\mathrm{n}$ & $\%$ \\
\hline Rendah & 14 & 43.7 & 7 & 11.1 & 4 & 16.0 & 25 & 20.8 \\
\hline Sedang & 16 & 50.0 & 53 & 84.2 & 12 & 48.0 & 81 & 67.5 \\
\hline \multirow[t]{2}{*}{ Tinggi } & 2 & 6.3 & 3 & 4.7 & 9 & 36.0 & 14 & 11.7 \\
\hline & & & & & & & 120 & 100.0 \\
\hline
\end{tabular}

Akun@KeSEMaT sering memberikan kuliah Twitter (kultwit) atau pemberian materi tentang mangrove yang disampaikan melalui beberapa tweet dalam suatu waktu tertentu. Materi kultwit biasanya berhubungan dengan ilmu pengetahuan mengenai mangrove atau hasil penelitian yang berhubungan dengan mangrove. Karena kultwit sifatnya saling berhubungan antara tweet yang satu dan yang berikutnya, maka responden harus memberikan waktu lebih lama dalam memperhatikan Time Line dari @ KeSEMaT agar dapat memahami kultwit tersebut.

\section{Hubungan Frekuensi dan Durasi Akses Twitter dengan Aspek Afekti}

Berdasarkan hasil perhitungan melalui rank spearman didapatkan hasil nilai signifikan antara tingkat frekuensi dan perubahan perilaku afektif sebesar 0.003 dengan koefisien korelasi sebesar 0.248 terdapat hubungan yang signifikan antara tingkat frekuensi keterlibatan dalam media sosial dan perubahan perilaku efektif dengan tingkat hubungan rendah tapi pasti. KeSEMaT melalui akun @ KeSEMaT sering menulis tweet berupa ajakan untuk ikut dalam pelestarian mangrove di Indonesia. Pesan persuasif yang disampaikan@KeSEMaT selalu dibarengi dengan fakta-fakta dan manfaat pentingnya masyarakat Indonesia melestarikan mangrove. Dengan frekuensi yang tinggi dalam membaca Time Line@KeSEMaT diharapkan followers dapat tertarik untuk ikut dalam gerakan pelestarian mangrove.

Berdasarkan hasil perhitungan melalui rank spearman didapatkan hasil nilai signifikan antara tingkat durasi dan perubahan perilaku afektif 0.000 dengan koefisien korelasi sebesar 0.459 terdapat hubungan yang signifikan antara tingkat durasi keterlibatan dalam media sosial dan perubahan perilaku afektif dengan tingkat hubungan cukup berarti. KeSEMaT melalui akun@KeSEMaT juga 
sering mengajak followers untuk berpartisipasi dalam kuis-kuis yang diadakan melalui@KeSEMaT. Pertanyaanpertanyaan mengenai kuis biasanya berhubungan dengan mangrove, dengan adanya kegiatan kuis tersebut responden memiliki durasi lebih lama membaca Time Line@ KeSEMaT.

Tabel 20. Jumlah dan Persentase Responden Menurut Frekuensi Mengakses Akun Twitter @KeSEMaT dan Aspek Afektif

\begin{tabular}{lcccccccr}
\hline $\begin{array}{l}\text { Frekuen- } \\
\text { si Akses } \\
\text { Twitter }\end{array}$ & \multicolumn{6}{c}{ Aspek Afektif } & \multirow{2}{*}{ Rumlah } \\
\cline { 2 - 7 } & Rendah & Sedang & \multicolumn{2}{c}{ Tinggi } & & \\
\hline Rendah & 6 & 37.5 & 15 & 20.0 & 3 & 10.4 & 24 & 20.0 \\
Sedang & 10 & 62.5 & 43 & 57.3 & 17 & 58.6 & 70 & 58.3 \\
Tinggi & 0 & 0.0 & 17 & 22.7 & 9 & 31.0 & 26 & 21.7 \\
& & & & & & & 120 & 100.0 \\
\hline
\end{tabular}

Tabel 21. Jumlah dan Persentase Responden Menurut Durasi Mengakses Akun Twitter@KeSEMaT dan Aspek Afektif

\begin{tabular}{|c|c|c|c|c|c|c|c|c|}
\hline \multirow{3}{*}{$\begin{array}{l}\text { Durasi } \\
\text { Akses } \\
\text { Twitter }\end{array}$} & \multicolumn{6}{|c|}{ Aspek Afektif } & \multirow{2}{*}{\multicolumn{2}{|c|}{ Jumlah }} \\
\hline & \multicolumn{2}{|c|}{ Rendah } & \multicolumn{2}{|c|}{ Sedang } & \multicolumn{2}{|c|}{ Tinggi } & & \\
\hline & $\mathrm{n}$ & $\%$ & $\mathrm{n}$ & $\%$ & $\mathrm{n}$ & $\%$ & $\mathrm{n}$ & $\%$ \\
\hline Rendah & 11 & 68.7 & 10 & 13.3 & 4 & 13.7 & 25 & 20.8 \\
\hline Sedang & 5 & 31.3 & 62 & 82.7 & 14 & 48.3 & 81 & 67.5 \\
\hline \multirow[t]{2}{*}{ Tinggi } & 0 & 0.0 & 3 & 4.0 & 11 & 38.0 & 14 & 11.7 \\
\hline & & & & & & & 120 & 100.0 \\
\hline
\end{tabular}

\section{EFEKTIVITAS MEDIA SOSIAL DALAM} KEIKUTSERTAAN KEGIATAN OFFLINE

Hubungan Aspek Kognitif dan Afektif dengan Keikutsertaan Kegiatan Offline

Tabel 22. Jumlah dan Sebaran Responden Berdasarkan Keikutsertaan Kegiatan Offline

Keikutsertaan Kegiatan Jumlah $\quad$ Persentase (\%) Offline

\begin{tabular}{lll}
\hline Rendah $(<5)$ & 34 & 28.3 \\
Sedang $(6-10)$ & 53 & 44.2 \\
Tinggi $(>11)$ & 33 & 27.5 \\
\hline
\end{tabular}

Berdasarkan hasil perhitungan melalui rank spearman didapatkan hasil nilai signifikan antara perubahan perilaku kognitif dan partisipasi offline sebesar 0.003 dengan koefisien korelasi sebesar 0.247 terdapat hubungan yang signifikan antara perubahan perilaku kognitif dan partisipasi offline dengan tingkat hubungan rendah tapi pasti.

Tabel 23 menunjukkan bahwa pada responden dengan aspek kognitif sedang dengan keikutsertaan kegiatan offline sedang memiliki persentase terbesar dengan jumlah $60.0 \%$. Salah satu responden yang berdomisili di Semarang mengungkapkan dengan mengetahui pentingnya mangrove melalui Twitter @KeSEMaT, responden pernah sekali ikut berpartisipasi dalam kegiatan KeSEMaT.

Berdasarkan hasil perhitungan melalui rank spearman didapatkan hasil korelasi antara perubahan perilaku afektif dan partisipasi offline sebesar 0.000 dengan koefisien korelasi sebesar 0.443 terdapat hubungan yang signifikan antara perubahan perilaku afektif dan partisipasi offline dengan tingkat hubungan yang cukup berarti.

Tabel 23. Jumlah dan Persentase Responden Menurut Aspek Kognitif dan Keikutsertaan Kegiatan Offline

\begin{tabular}{lcccccccr}
\hline $\begin{array}{l}\text { Aspek } \\
\begin{array}{l}\text { Kog- } \\
\text { nitif }\end{array}\end{array}$ & \multicolumn{3}{c}{ Keikutsertaan Kegiatan Offline } & \multicolumn{2}{c}{ Jumlah } \\
\cline { 2 - 10 } & \multicolumn{2}{c}{ Rendah } & \multicolumn{2}{c}{ Sedang } & \multicolumn{2}{c}{ Tinggi } & & \\
\hline & $\mathrm{n}$ & $\%$ & $\mathrm{n}$ & $\%$ & $\mathrm{n}$ & $\%$ & $\mathrm{n}$ & $\%$ \\
\hline Rendah & 11 & 47.9 & 16 & 26.7 & 5 & 13.5 & 32 & 26.7 \\
$\begin{array}{l}\text { Se- } \\
\text { dang }\end{array}$ & 7 & 30.4 & 36 & 60.0 & 20 & 54.0 & 63 & 52.5 \\
$\begin{array}{l}\text { Tinggi } \\
\text { Jum- }\end{array}$ & 5 & 21.7 & 8 & 13.3 & 12 & 32.5 & 25 & 20.8 \\
lah & & & & & & & 120 & 100.0 \\
\hline
\end{tabular}

Tabel 24. Jumlah dan Persentase Responden Menurut Aspek Afektif dan Keikutsertaan Kegiatan Offline

\begin{tabular}{|c|c|c|c|c|c|c|c|c|}
\hline \multirow{3}{*}{$\begin{array}{l}\text { Aspek } \\
\text { Afektif }\end{array}$} & \multicolumn{6}{|c|}{ Keterlibatan Secara Offline } & \multirow{2}{*}{\multicolumn{2}{|c|}{ Jumlah }} \\
\hline & \multicolumn{2}{|c|}{ Rendah } & \multicolumn{2}{|c|}{ Sedang } & \multicolumn{2}{|c|}{ Tinggi } & & \\
\hline & $\mathrm{n}$ & $\%$ & $\mathrm{n}$ & $\%$ & $\mathrm{n}$ & $\%$ & $\mathrm{n}$ & $\%$ \\
\hline Rendah & 11 & 47.9 & 4 & 6.7 & 1 & 2.7 & 16 & 13.3 \\
\hline Sedang & 7 & 30.4 & 51 & 85.0 & 17 & 45.9 & 75 & 62.5 \\
\hline Tinggi & 5 & 21.7 & 5 & 8.3 & 19 & 51.4 & 29 & 24.2 \\
\hline Jumlah & & & & & & & 120 & 100.0 \\
\hline
\end{tabular}

\section{KESIMPULAN DAN SARAN}

\section{Kesimpulan}

Media sosial Twitter telah dimanfaatkan KeSEMaT sebagai salah satu sarana kampanye gerakan sosial pelestarian mangrove. Dengan menggunakan Twitter pesan-pesan kampanye pelestarian mangrove lebih mudah disampaikan dan memudahkan interaksi antara KeSEMaT dengan para pengguna Twitter. Hasil penelitian menunjukkan bahwa:

a. Followers mengakses Twitter sebanyak 2 sampai 3 kali perhari dengan durasi 40 sampai 60 menit. Sedangkan followers membaca tweet dari akun@KeSEMaT sebanyak 4 sampai 5 kali perhari dengan durasi 8 sampai 10 menit. Dalam mengakses Twitter, followers dipengaruhi oleh pendidikan, pendapatan, pengeluaran untuk akses internet, dan kepemilikan perangkat TIK

b. Akses terhadap akun Twitter @KeSEMaT efektif dalam mengubah perilaku dan sikap followers terhadap pelestarian mangrove. Semakin tinggi frekuensi dan durasi mengakses akun@KeSEMaT maka semakin tinggi 
perubahan perilaku yang terjadi.

c. Perubahan perilaku efektif dalam menggerakkan followers untuk terlibat dalam kegiatan offline. Semakin tinggi perubahan perilaku, semakin tinggi pula keterliabatan followers dalam kegiatan offline pelestarian mangrove.

\section{Saran}

Media sosial khususnya Twitter telah menjadi bagian dari kehidupan banyak masyarakat, tidak hanya digunakan untuk komunikasi antar teman kini media sosial telah menjadi sarana untuk mengajak orang untuk terlibat dalam gerakan sosial. Pesan yang disampaikan melalui akun@KeSEMaT yang selama ini dipublikasikan terbukti telah mampu mengajak banyak kalangan untuk terlibat dalam kegiatan pelestarian mangrove. Konten-konten yang di tweet oleh akun@KeSEMaT kedepannya diharapkan mampu lebih menyampaikan sifat pesan yang $5 \mathrm{~W}+1 \mathrm{H}$, penggunaan bahasa-bahasa yang lebih populer, menampilkan gambargambar kegiatan, memperbanyak informasi mengenai kegiatan pelestarian mangrove yang telah dilaksanakan, penggunaan mention pada followers dalam ajakan dalam kegiatan, dan lebih banyak dalam produksi tweet.

\section{DAFTAR PUSTAKA}

Azwar S. 2005. Sikap Manusia, Teori dan Pengukurannya. Yogyakarta (ID): Pustaka Pelajar.

Bungin B. 2009. Sosiologi Komunikasi: Teori, Paradigma, dan Diskursus Teknologi Komunikasi di Masyarakat. Jakarta (ID):Kencana.

Darwin W. 2013. MarkPlus Insight: Pengguna Internet Indonesia 74 Juta di tahun 2013 [Internet]. themarketeers. [Diunduh 2014 Januari 22]. Tersedia pada: http://www.the-marketeers.com/archives/ Indonesia\%20Internet \% 20Users.html\#.UuAJphDLIV

Emarita N. 2012. Hubungan antara Pencarian Informasi melalui twitter@BdgBerkebun dengan pemenuhan kebutuhan informasi. eJurnal Mahasiswa Universitas Padjajaran. [Internet]. [Diunduh 2012 November 12]; 1(1):1-14. Tersedia pada: http://jurnal.unpad. ac.id/ejournal/article/view/1841/pdf_34

Ismail A. Akademi Berbagi : gerakan sosial di dunia digital. [thesis]. [Internet]. [Diunduh 2012 November 24]. [Universitas Indonesia]. Tersedia pada: http://lontar.ui.ac.id/ file? file $=$ digital $/ 20299066 \mathrm{~T} 30007 \mathrm{Ahmad} \% 20$ Ismail.pdf

Kaplan Andreas M, Haenlein M. 2010. Users of the world, unite! The challenges and opportunities of Social Media. Bussines Horizons [Internet]. [Diunduh 2013 Des 11]; 53(1):59-68. Tersedia pada: http:// www.sciencedirect.com /science/article/pii/ S0007681309001232

Kristo FY. 2013. Posisi Indonesia di Percaturan Teknologi Dunia: Jumlah Pengguna Media Sosial. [Internet]. detikinet. [Diunduh 2014 Januari 22]. Tersedia pada: http://inet.detik.com/read/2013/08/21/11220 7/2336008/398/5/posisi-indonesia-di-percaturan- teknologi-dunia.

Loisa R. 2011. Jejaring Sosial, Identitas Kolektif dan Aksi Politik. Faktor facebook dalam Revolusi Mesir. Jurnal Komunikasi Universitas Tarumanegara. [Internet]. [Diunduh 2012 November 26]. III(01):3044. Tersedia pada: http://journal.tarumanagara.ac.id/ index.php/FIKOM/article/viewFile/1138/1230

Nugroho, Y. 2011. @ksi warga: kolaborasi, demokrasi partisipatoris dan kebebasan informasi. Memetakan aktivisme sipil kotemporer dan penggunaan media sosial di Indonesia. (Alih bahasa dari bahasa Inggris oleh Sujono AY). [Internet]. [Diunduh 2013 November 30]. Tersedia pada: http://audentis. files.wordpress.com/2011/04/citizens-in-actionmioirhivos-final_report-in.pdf

Pitoyo, N. 2011. Pengguna Situs Apa Paling terdidik?. [Internet]. teknologi. [Diunduh 2014 Januari 24]. Tersedia pada: http://teknologi.inilah.com / $\mathrm{read} /$ detail/1722172/pengguna-situs-apa-palingterdidik\#.UuFXVhD-LIU

Putri, UD. 2012. Peran Media Baru dalam Membentuk Gerakan Sosial. Studi Kasus pada Individu yang terlibat dalam Indonesia Unite di twitter). [skripsi]. [Internet]. [Diunduh 2012 November 12]. [Universitas Indonesia]. Tersedia pada: 2http://lontar.ui.ac.id/file?file=digital $/ 20289661 \mathrm{~S}$ Dibyareswari\%20Utami\%20Putri.pdf

Rakhmat J. 2002. Metode Penelitian Komunikasi. Bandung (ID): PT Remaja Rosdakarya.

Rahmawati D. 2010. Hegemoni dalam facebook. Studi kasus Gerakan Satu Juta Dukungan Facebooker Bagi Bibit-Chandra. [thesis]. [Internet]. [Diunduh 2012 November 24]. [Universitas Indonesia]. Tersedia pada: http://lontar.ui.ac.id/ file?file $=$ digital $/ 131535-\mathrm{T} \% 2027585-$ Hegemonifull\%20text.pdf

Stzompka P. 1993. Sosiologi: Perubahan Sosial. Alimandan, penerjemah. Jakarta (ID): Prenada. Terjemahan dari : Sosiology of Social Change.

Sugiyono. 2011. Statistika untuk Penelitian. Bandung (ID): Alfabeta. 